\author{
Aleksandra Julia Leinwand \\ https://orcid.org/0000-0001-9849-0842 \\ Tadeusz Manteuffel Institute of History, Polish Academy of Sciences
}

\title{
Soviet propaganda and the independent Polish state
}

\author{
"But no Marxist, without renouncing the principles of Marxism \\ and of socialism generally, can deny that the interests of social- \\ ism are higher than the interests of the right of nations to \\ self-determination." (Lenin)
}

Zarys treści: Artykuł ukazuje powstanie niepodległego państwa polskiego w 1918 r. w oświetleniu propagandy sowieckiej. Punktem wyjścia są najważniejsze dokumenty dyplomatyczne i akty propagandowe skierowane do Polaków lub traktujące o kwestii niepodległości Polski wystosowane przez mocarstwa rozbiorowe (Niemcy, Austro-Węgry, Rosja) oraz USA w trakcie Wielkiej Wojny. Po przewrocie bolszewickim w 1917 r. władze nowopowstałego państwa - Rosji Sowieckiej - musiały zająć stanowisko wobec odrodzonej Polski. Autorka analizuje wybrane teksty dyplomatyczne i propagandowe oraz „wytwory” propagandy plastycznej odnoszące się do niepodległego państwa polskiego.

Content outline: The article presents the establishment of the independent Polish state in 1918 in the light of Soviet propaganda. Its starting point are the most important diplomatic documents and propaganda acts addressed to Poles or relating to the matter of Poland's independence, issued by the partitioning powers (Germany, Austria-Hungary, Russia) and the USA during the Great War. Following the Bolshevik revolution of 1917, the authorities of the newly formed state-Soviet Russia-had to adopt a stance towards reborn Poland. The author analyses selected diplomatic and propaganda texts and "products" of artistic propaganda related to the subject of the independent Polish state.

Słowa kluczowe: Polska; Rosja; niepodległość; rewolucja 1917; wojna polsko-sowiecka 19191920; propaganda bolszewicka

Keywords: Poland; Russia; independence; revolution of 1917; Polish-Soviet War 1919-1920; Bolshevik propaganda

With an increasingly evident perspective of a global armed conflict, the turn of the $19^{\text {th }}$ and $20^{\text {th }}$ centuries revived the aspirations of the subjugated nations of Europe. It was a sad paradox that the outbreak of a war constituted an opportunity for them to emerge. Among those awaiting an opportunity to effectively claim their 
rights were the Poles, who had been deprived of their own state since the end of the $18^{\text {th }}$ century as a result of partitions carried out by neighbouring powers: Russia, Prussia and Austria. Poland's tragedy relied in the fact that its subjects were drafted by the partitioning states into their armies, resulting in a fratricidal fight on opposite sides of the frontlines. Poland's hope thus lay in the prospect of regaining independence.

After a long period of absence (or very weak presence) of the Polish cause in the international arena, the outbreak and spread of armed conflict opened a new chapter. From the very beginning, Polish territories became the scene of operations of German, Austro-Hungarian and Russian armies. The rulers of the partitioning powers, especially the Russians, feared the internationalisation of the Polish cause and the revival of sympathies for Poland in England and France, as it had occurred in the $19^{\text {th }}$ century during and after the fall of anti-Russian armed uprisings. Russia was concerned by its own allies within the Entente. The authorities in Petersburg were thus all the more wary of the plans that the Central Powers had concerning Poland. In the light of these new circumstances, the Russians, Austrians and Germans had to start reckoning with the Polish opinion. They also made a number of steps aimed at winning the favour of Poles.

The Russian side was the first to express its opinion on the Polish issue. Shortly after the outbreak of the war, on 14 August 1914, the commander-in-chief of the Russian army, Grand Duke Nicholas Nikolaevich, issued a proclamation addressed to the Poles. The document bore his signature, not the Tsar's (which was prevented by the Russian ministers who were unfavourable towards Poland), which absolved Nicholas II from responsibility for the promises contained in the proclamation.

Here are some excerpts from the message addressed to the Poles at the beginning of the Great War by their eternal enemies:

The hour has come when the dream of your fathers and your grandfathers may come true. One and a half centuries ago, the living body of Poland was torn to pieces, but its soul did not perish. She lived in the hope that the hour of resurrection would come for the Polish Nation and for fraternal reconciliation with Great Russia.

The Russian army brings you the blissful news of this reconciliation. May the borders that cut the Polish nation into parts be blurred.

Let the Polish nation merge into one body under the sceptre of the Russian Emperor. Under this sceptre Poland will be reborn, free in its faith, language and self-government. $[\ldots]$ The aurora of new life is rising for you. $[\ldots]^{1}$

The authors of the proclamation ignore the fact that this "Great Russia" was one of the three powers that "one and a half centuries ago, had torn to pieces the

\footnotetext{
${ }^{1}$ K. W. Kumaniecki, Odbudowa państwowości polskiej. Najważniejsze dokumenty. 1912 - styczeń 1924, Warszawa-Kraków, 1924, p. 27.
} 
living body of Poland," and then, by suppressing the aspirations for independence and combating all manifestations of Polishness, it did everything to ensure that, contrary to pompous declarations, "its soul shall perish." However, a cold-headed analysis of this text leads to the conclusion that the August Manifesto represented an excellent exploitation of the situation in terms of propaganda. The content of the proclamation was consistent with the ideology of National Democracy, the most influential Polish party (the National Democrats opted for an agreement with Russia while expressing a very strong anti-German attitude). Thus, the Russian message struck the minds and hearts of Poles who supported Roman Dmowski's party, but it was a serious problem for Józef Piłsudski (a socialist with a pro-independence attitude, an opponent of Dmowski) and his concept of military struggle. As one researcher remarked, the proclamation of the commander-in-chief of the Russian army was the first time in the history of Russia when the Polish nation was addressed directly. ${ }^{2}$

The proclamation of the Russian Grand Duke also had addressees other than Poles, although it was not indicated in the text. The Russians competed for the favour of the Poles with their former allies who had recently become their enemies, i.e. Germany and Austria-Hungary. They were also taken into account by the authors of the proclamation, along with the governments of Western countries that were members of the coalition. ${ }^{3}$

When evaluating the significance of the proclamation of 14 August 1914, Aleksander Achmatowicz, specialist in the history of Russia and the history of the First World War, noted that it fitted a bidding war of promises that would touch on aspects important for the Polish cause during the wartime period. ${ }^{4}$

${ }^{2}$ Historia dyplomacji polskiej, vol. 3: 1795-1918, ed. L. Bazylow, part 4, Warszawa, 1982, p. 805.

3 Stanisław Kutrzeba pointed out that when the war broke out, neither Germany nor Austria "had a programme with regard to the Polish question, neither a common one nor their own." Unlike Russia, which "decided to win the Poles over, and could do so all the easier as they posed no threat, but on the contrary it could bring benefits and present Russia's activity as a symptom of high ethical qualification." "The Grand Duke's proclamation, full of noble, carefully selected themes, was received very kindly in the West [...]." (S. Kutrzeba, Polska Odrodzona 1914-1939, $5^{\text {th }}$ ed., Kraków, 1988, pp. 23, 2425). Henryk Wereszycki in turn noted that "the Russian manifesto was the most well written proclamation addressed to Poles that appeared during the Great War [and] it differed especially favourably from the simultaneously issued proclamations of Austrian and German military authorities." "Regardless even of the intentions of the manifesto's authors, it gave Russia an advantage over the Central Powers in the fight for public opinion, since the latter had shown particular ineptitude in this matter." (H. Wereszycki, Historia polityczna Polski 1864-1918, $2^{\text {nd }}$ ed. revised and expanded, Paryż, 1979, p. 273).

4 Therefore, according to the historian, "the proclamation that had nothing to do with the idea of Poland's independence, also marked the beginning of Poland's path to independence, although this was not the intention of its initiator, i.e. the head of Russian diplomacy until July 1916, Minister Sazonov." (A. Achmatowicz, Polityka Rosji w kwestii polskiej w pierwszym roku Wielkiej Wojny 1914-1915, Warszawa, 2003, p. 311-312. The entirety of the extensive chapter 8 of this book is devoted to this proclamation.) 
Subsequent "addresses" to Poles were closely related to the situation on the frontlines of the Great War and its consequences. After months devoid of progress in relation to the Polish issue, new circumstances arose in 1915 with the occupation of the Kingdom of Poland by the Central Powers. A dozen million Poles found themselves under the new rule. The emperors of Germany and AustriaHungary, increasingly burdened by the war, understood the importance of this military potential.

At the beginning of November 1916, the Austrian governor-general in Lublin (in the part of the Kingdom of Poland occupied by the Austro-Hungarian army), Karl von Kuk, issued, on behalf of Emperor Franz Joseph I, the proclamation "To the residents of the Lublin General Government," the so-called Act of 5 November. On the same day a similar proclamation on behalf of German Emperor Wilhelm II was issued by Warsaw Governor General Hans von Beseler.

The language of this proclamation is telling: rich in pathos and ornaments, which were supposed to cover the negligible number of specifics. It began as follows: "Overwhelmed by the unwavering trust in the final victory of their armies and by the desire that the Polish lands, pried through heavy sacrifice of their brave armies from the Russian rule, be led to a joyous future [...]," the Austrian and German emperors "have come together to make these lands into an independent state with a hereditary monarchy and a constitutional system. [...] The glorious traditions of the Polish military of yesteryear and the memory of the brave Polish brothers-in-arms will continue to live in their own army in this Great War." In its last part, the authors of the proclamation expressed their hope that the wishes of political and national prosperity of the Kingdom of Poland be fulfilled. They also assured that the great powers neighbouring the Kingdom of Poland from the west would be happy to witness at their eastern borders the resurrection and blossoming of a "free happy and nationally self-conscious state."

The restoration of the independent Polish state was not, of course, the objective of Germany or the Austro-Hungarian Empire. However, the act of 5 November turned out to be more than a collection of propaganda clichés imposed by the need of the moment. The Polish issue has once again been brought to the international arena, and this by the rulers of still powerful states, which were also the partitioning powers. Over time practically every government involved in the war had expressed itself in this matter.

On 22 January 1917 the president of the still neutral United States declared in his address to the Senate that, among other things: "I take it for granted, for instance, if I may venture upon a single example, that statesmen everywhere are agreed that there should be a united, independent, and autonomous Poland, and that henceforth inviolable security of life, of worship, and of industrial and social development should be guaranteed to all peoples who have

${ }^{5}$ K. W. Kumaniecki, op. cit., p. 48. 
lived hitherto under the power of governments devoted to a faith and purpose hostile to their own."

To complement the American topic (or rather: the Polish topic in American politics), let us recall that one year later, on 8 January 1918, Thomas Woodrow Wilson addressed a message to the US Congress in which he presented a peace programme for the world and international guarantees to ensure liberty and freedom of development for all nations. The thirteenth item of that message referred to Poland and read as follows: "An independent Polish state should be erected which should include the territories inhabited by indisputably Polish populations, which should be assured a free and secure access to the sea, and whose political and economic independence and territorial integrity should be guaranteed by international covenant." 7

The existence of an independent Polish state was therefore, in the understanding of the representatives of the free world, one of the indispensable elements of the future post-war order.

The revolution in Russia proved to be a shock on a global scale. In February (March) 1917 the Tsarist regime was overthrown, which entailed consequences relating, among others, to Polish affairs. After the victory of the democratic revolution in Russia, the Provisional Government was formed, but at the same time there also appeared a system of councils of workers' and soldiers' delegates.

On 27 March the Petrograd Council of Workers' and Soldiers' Delegates addressed a message to the Polish nation. It is worth quoting this short text in its entirety because of its importance.

The Tsarate, which had stifled both the Polish and the Russian people over the course of one and a half centuries, was overthrown by the joint forces of the proletariat and the army. While communicating this victory of freedom over the all-Russian gendarme to the Polish nation, the Petrograd Council of Workers' and Soldiers' Deputies declares that democracy in Russia stands for the recognition of the political self-determination of nations and declares that Poland has the right to complete independence in terms of state and international affairs.

We send our warmest greetings to the Polish people and wish them every success in their fight for the establishment of a democratic republican system in independent Poland. ${ }^{8}$

The political significance of the above message consisted mainly in the fact that this was the first official Russian declaration on the Polish issue after the overthrow of the Tsarist regime. One should also take notice of the moral dimension

${ }^{6}$ Papers Relating to the Foreign Relations of the United States. 1917. Supplement 1. The World War, Washington, 1931, p. 27.

7 Papers Relating to the Foreign Relations of the United States. 1918. Supplement 1. The World War, vol. 1, Washington 1933, p. 16.

8 Powstanie II Rzeczypospolitej. Wybór dokumentów 1866 - 1925, ed. H. Janowska, T. Jędruszczak, Warszawa, 1981, p. 332. 
of this message. It is rightly emphasised, ${ }^{9}$ however, that only the proclamation of the newly formed Provisional Government of 29 March 1917 has proved to be a document of fundamental importance for international law. Much has been written on this subject. In my deliberations, I would like, first of all, to draw attention to the agitational aspect of the text being discussed. The proclamation begins as follows:

"Poles! The former political government of Russia, the source of your captivity and our destruction, has fallen forever. The freed Russia, embodied by the provisional government which it has empowered, sends you fraternal greetings. It calls you to life and freedom." ${ }^{10}$ Next, the authors draw attention to the "false promises" made to Poles by the "old government" and appeal: "Polish brothers! The hour of the great ruling has come for you as well. Free Russia calls on you to fight within your ranks for the freedom of your nation." Alongside slogans about "paying for the blood of the [Polish] nation" by the Central Powers and plans for a joint fight of Poles and Russians "against the Germanic world," the text also contains important declarations. It therefore grants "the Polish fraternal nation the full right to determine its own fate according to its own will" and declares support "for the creation of an independent Polish state from all territories in which Poles make up a majority, as a guarantee of lasting peace in a future, newly organised Europe." It is asserted that "the free United Poland would define its own form of government by expressing its will in a constituent assembly convened to the capital of Poland on the principles of universal voting rights."

At the same time, however, the text mentioned the "Polish state being connected with Russia by a free military union" and announced that "the Russian Constituent would eventually confirm the new brotherly union." The above statements were difficult to accept for those Polish communities whose ultimate goal was a completely self-reliant and independent Poland. The proclamation of the Russian Provisional Government had a positive impact on the West. The allied powers (England, France and Italy), for whom such an act appeared to be very convenient, issued notes expressing their solidarity with Russia's position on the Polish issue. ${ }^{11}$

It is worth noting the ending of the proclamation. Not because of the renewed call to Polish brothers to embrace the hand presented to them by free Russia, or because of the slogans encouraging to fight together, but because of the last words of this text: "For your freedom and ours!" This slogan was devised by the prominent Polish historian and politician Joachim Lelewel (1786-1861). The notion contained in the quoted words was traditionally important for Poles and Russians

\footnotetext{
${ }^{9}$ Cf.: P. Łossowski, “Geneza niepodległości. Dyplomacja II Rzeczypospolitej," in: Historia dyplomacji polskiej X-XX w., Warszawa, 2002, p. 450.

${ }^{10}$ K. W. Kumaniecki, op. cit., p. 67. (Subsequent quotes from the same source).

${ }^{11}$ Cf.: Powstanie II Rzeczypospolitej..., docs. 149 and 150.
} 
with democratic convictions alike. However, they were not the only ones to use Lelewel's slogan, which will be discussed below.

This quick and incomplete overview of diplomatic documents raising the Polish issue, and of proclamations of an agitational nature addressed to Poles during the First World War proves that the subject of Poland could no longer be ignored. By observing the European theatre of warfare and politics, one can conclude that the successive collapses of empires were accompanied by an increase in the importance of the Polish cause. This resulted both from a combination of circumstances and, to a large extent, from the actions of Poles who, on various levels, tried to take advantage of those circumstances. In short, it was on the one hand the military activity of the Legions of Józef Piłsudski, and on the other hand the diplomatic activity of Roman Dmowski within the framework of the National Committee of Poland cooperating with the Coalition states.

In November 1917, following a military coup, the Bolsheviks seized power in Russia. The new rulers of the "state of workers and peasants" in statu nascendi addressed the world with a message completely different from that of their predecessors from Petersburg. On 8 November 1917, i.e. immediately after the Bolshevik coup, the Peace Decree edited by Lenin was issued, which clearly spoke out against the annexation of foreign lands and the use of violence against nations. ${ }^{12}$ Further documents were soon published: the Declaration of the Rights of the Nations of Russia (15 November) signed by the People's Commissar for National Affairs, Stalin, and the President of the Council of People's Commissars, Lenin, and the Declaration of the Rights of the Working and Exploited People (passed on 16 January 1918 by the All-Russian Central Executive Committee). The former proclaimed "the equality and sovereignty of the peoples of Russia" and "the right of the peoples of Russia to free self-determination including the right to secede and form an independent state," the latter also advocated free self-determination of the peoples. ${ }^{13}$

These glorious claims contained in the above statements were totally at odds with reality. The two-track approach present in the politics of the Russian Soviet Federative Socialist Republic (RFSRR) was striking from the very beginning, especially with regard to the question of the self-determination of nations. It is impossible to discuss here the course of a long-lasting dispute on this subject, which had been taking place within the Second International since the end of the $19^{\text {th }}$ century. As Leszek Kołakowski noted: "the question of nationality was a permanent, unsolved theoretical difficulty of Marxism and a practical difficulty of social movements."14

According to Lenin, who had shown interest in national issues and expressed his opinion on these issues many times (notably in his articles from 1903), the

12 W. I. Lenin, Dzieła, vol. 26, Warszawa, 1953, pp. 239-242.

13 Dokumenty vneshnei politiki SSSR, vol. 1, Moskva, 1957, pp. 14-15; W. I. Lenin, op. cit., vol. 26, p. 432.

${ }^{14}$ L. Kołakowski, Main currents of Marxism. Its rise, growth, and dissolution, vol. II: The Golden Age, transl. P. S. Falla, Oxford, 1978, p. 88. 
right of nations to self-determination should be dependent on the "interests of the proletariat." In practice, the Bolshevik leader referred to the principle of self-determination only when it was convenient. In other words, evoking the rights of nations served as a tactical measure. After gaining power, the Bolsheviks faced the problem of reconciling the idea of a world revolution, which was to abolish national borders with the promise of emancipation of nations. ${ }^{15}$ They dealt with this issue with utmost skilfulness. This is an example illustrating the instrumental approach of Bolshevik leaders to national issues.

In January 1918, at the same time when the Declaration of the Rights of the Working and Exploited People was announced, Stalin, in his speech at the Third Congress of the Councils, invoked "the need to interpret the principle of self-determination as the right to self-determination not of the bourgeoisie, but of the working masses of a given nation. The principle of self-determination should be a means of fighting for socialism and should be subordinated to the principles of socialism." 16

And at the end of March 1918, Lenin published an article entitled Immediate Tasks of the Soviet Government, in which he wrote, among other things: "In the example of the Russian Soviet Republic we see most graphically that the federation we are introducing will serve now as the surest step to the most solid unification of the different nationalities of Russia into a single, democratic, centralised Soviet State." 17

Richard Pipes accurately described Lenin's attitude towards national issues and the successes of the Bolshevik policy in this field. "Lenin looked upon national problems as something to exploit, and not as something to solve. But as a psychological weapon in the struggle for power, first in Russia and then abroad, the slogan of self-determination in Lenin's interpretation was to prove enormously successful. The outbreak of the Russian Revolution allowed the Bolsheviks to put it to considerable demagogic use as a means of winning the support of the national movements which the revolutionary period developed in all their magnitude."18

As shown above, almost all major governments officially expressed their views on Poland in various forms. The Polish people were usually addressed at breakthrough moments, for instance by Russians two weeks after the outbreak of the war (in mid-August 1914), and then by "other Russians" after the overthrow of the Tsarist regime (in March 1917). It may appear surprising that in the first months after the October Coup, official Soviet documents and declarations lacked a clear position on the issue of Poland's independence. This was no coincidence

15 Cf.: A. J. Leinwand, Czerwonym młotem w orła białego. Propaganda sowiecka w wojnie z Polska 1919-1920, Warszawa, 2008, pp. 63-64.

16 J. W. Stalin, op. cit., vol. 4, Warszawa, 1951, pp. 43-44.

17 W. I. Lenin, op. cit., vol. 29, p. 209.

18 R. Pipes, The Formation of the Soviet Union. Communism and Nationalism 1917-1923, Cambridge, Massachusetts, 1970, p. 49. 
though. The Bolsheviks counted on a "socialist nature of self-determination," on the outbreak of the revolution in Poland, which would make it a point of departure for revolutionary Germany and in which Soviet Russia was willing to help.

During the peace negotiations held since December 1917 in Brest-Litovsk, the Polish issue became the subject of Russian-German-Ukrainian bargains. It also proved to be a very useful propaganda tool for the Bolsheviks. Trotsky presented himself as a defender of Polish interests, and so did the Soviet press and agitation prints. ${ }^{19}$ On 9 February 1918 the Central Powers signed a separate peace agreement with Ukraine, and on 3 March a treaty was concluded with Soviet Russia (later annulled by them in November 1918).

It was not until 29 August 1918, i.e. almost one year after the Bolshevik coup d'état, that the decree of the Council of People's Commissars was published, with a fragment touching on the cancellation of partitions and on Poland's right to independence. It read as follows: "All agreements and acts concluded by the Government of the former Russian Empire with the Governments of the Kingdom of Prussia and the Austro-Hungarian Empire referring to the partitions of Poland are irrevocably annulled by the present decree, since they are contrary to the principle of the self-determination of peoples and to the revolutionary-legal conceptions of the Russian people, which recognises the inalienable right of the Polish nation to independence and unity." 20

Piotr Wandycz remarked that "this passage [is] often erroneously called the decree annulling Poland's partitions." ${ }^{21}$ The issues raised by the Polish-American

19 Piotr Wandycz stressed that "Soviet Russia appeared as a true friend of the Poles." During the talks in Brest-Litovsk "Trotsky and the other Soviet delegates [...] repeatedly made the point that they rejected German arguments 'not because we want to keep Poland for Russia, but because we want the Polish people themselves to say what their political destiny is to be" (quote from the article "Interview with com. Trotsky" published in Izvestia of 20 December 1917/2 January 1918, after: P. S. Wandycz, op. cit., p. 43). Wojciech Materski described the circumstances of the conclusion of the treaty and the future impact of these events as follows: "The withdrawal of Soviet Russia from the war and the conclusion of a peace treaty (in Brest-Litovsk) with the Central Powers, which established the course of the Austro-Ukrainian borderline in a manner particularly harmful to the Kingdom of Poland, brought a foretaste of the problems that the future independent Polish state was to face when defining its eastern borders." (W. Materski, $\mathrm{Na}$ widecie. II Rzeczpospolita wobec Sowietów 1918-1943, Warszawa, 2005, pp. 11-12).

20 Stosunki Rzeczypospolitej Polskiej z państwem radzieckim 1918-1943. Wybór dokumentów, compiled by P. Kołakowski, Warszawa, 1991, p. 30.

${ }^{21}$ Then, when analysing "the only official act by the Council of Peoples' Commissars referring to Poland" the historian puts forward several essential questions. "Why did the Bolsheviks unilaterally annul the partitions treaties, and why did they choose the autumn of 1918 to do so? If the objective was propaganda it is strange that the denunciation of the partitions did not come simultaneously with Soviet rejection of all secret treaties concluded by the old regime, or even at the time of the Brest-Litovsk negotiations. It may well be that the Bolsheviks felt that such a move would be a challenge to the Central Powers, and they could afford to make it only in August 1918. This does not explain why this declaration [...] was inserted in a document dealing with technical and non-controversial matters. Surely this deprived it of the publicity 
researcher remain valid. The intentional omission of the issue of Poland's independence resulted from the Bolsheviks' rejection of Polish aspirations and efforts to rebuild their own state. These pro-independence efforts were favoured (or at least not officially opposed) by Western governments. The leaders of the Russian SFSR had other plans, in which there was no place for newly emerging sovereign states. Their vision of the new order in Europe and, consequently, in the entire world was shared by left-wing activists of different nationalities (internationalists), united by the idea of social liberation which would result in freedom for the proletariat and the elimination of "property-owning classes." The nation states were condemned to death under the blows of the inevitable and, as was believed, victorious world revolution.

The Bolsheviks could count on support from Polish internationalists from the milieus of the Social Democracy of the Kingdom of Poland and Lithuania (SDKPiL), which was soon to transform into a communist party. These activists proved very useful to the architects of the Sovietisation of Europe. The discussed period of the World War and its conclusion is a time when the choice between revolution (identified as liberation of the working class) or regaining independence ceased to be theoretical and gained a practical dimension. The situation required a decision. ${ }^{22}$

In their diplomatic and agitational message addressed to the world (including the Poles), the rulers of Bolshevik Russia did not even intend to create the impression that they supported the creation of an independent Polish state. A clear position on this issue was expressed in the programme article of the People's Commissar for Nationalities, Stalin. The text entitled "Partition Wall" appeared on 17 November 1918 in the official periodical of the Commissariat for Nationalities Zhizn Natsionalnostei. ${ }^{23}$

The time and circumstances of the publication of this article are quite important: it was issued a few days after the ceasefire in Compiègne and the cessation of combat on the frontlines of the Great War, and after the withdrawal of the Bolsheviks from the Brest Treaty. Independent states, including Poland, were

which it otherwise could have achieved. The decree was made public in early September. One looks in vain for any evidence of Polish reaction. It would seem that the Bolsheviks, masters in revolutionary propaganda, did not direct the document at the Polish audience. It is also curious that the passage contained no reference to the Peace Decree or the Declaration of Rights of the Peoples of Russia but spoke in general terms about self-determination and revolutionary legality" (P. S. Wandycz, op. cit., pp. 61-62).

22 This issue is covered extensively in literature. Hélène Carrère d'Encausse, Roman Szporluk and Leszek Kołakowski have all written about it from a broader perspective; see also: A. J. Leinwand, "Po co Polakom niepodległość? Spór w socjaldemokracji polskiej na polskiej na przełomie XIX i XX wieku," in: Imperia, narody i społeczeństwa Europy Wschodniej i Środkowej na progu pierwszej wojny światowej, ed. A. Nowak, in cooperation with M. Banaszkiewicz, Warszawa, 2016, pp. 465-499.

${ }^{23}$ I am using the translated version: J. W. Stalin, Dzieła, vol. 4, Warszawa, 1951, pp. 177-178. 
emerging from the ruins of the Austro-Hungarian Empire, the German Empire and the German occupation areas. Their existence threatened to disrupt the revolutionary project of the Bolsheviks, while Germany overtaken by the revolution filled with hope. Russia spared no effort to "spill over" the revolution into as large an area as possible. They were operating both through faits accomplis and propaganda.

On 17 November, Soviet troops began their march westwards, in pursuit of the German troops leaving the Ober-Ost area (Oberkommando Ost). The objective of the Bolsheviks was to take control of Belarus and the Vilnius region, as well as Latvia and Estonia. Stalin's aforementioned article was published around the launch of the military action.

The author begins by saying that "between socialist Russia and the revolutionary West a partition wall has been erected in the shape of the occupied regions." We then read: "Whereas in Russia the Red flag has been waving for over a year now, and in the West, in Germany and Austria-Hungary, outbreaks of proletarian uprisings are multiplying daily and hourly, in the occupied regions, in Finland, Estonia, Latvia, Lithuania, Byelorussia, Poland, Bessarabia, the Ukraine and the Crimea, bourgeois nationalist 'governments' continue to drag out a wretched existence by the grace of the imperialists of the West whose time is coming to an end." 24 Polish historian Wiktor Sukiennicki rightly pointed out that in his writings Stalin placed a sign of equality between Poland and other provinces of the former Russian Empire. ${ }^{25}$

The People's Commissar for Nationalities was openly contemptuous of the "kinglets" and the "puny 'national' 'governments' [with the words 'governments' and 'national,' tellingly, in quotation marks] which have found themselves between the two tremendous conflagrations of revolution, in the East and in the West." ${ }^{26}$ The obstacle in the form of the resurgent independent states was to be easily eliminated. "We do not doubt that the mighty waves of revolution in Russia and the West will ruthlessly sweep away the counter-revolutionary dreamers in the occupied regions. [...] We have no reason to doubt that the counterrevolutionary partition wall between the revolutionary West and socialist Russia will in the end be swept away." 27

The article entitled "Partition Wall," despite its par excellence propagandist nature, must be taken seriously as it provides an overview of the Soviet ethnic policy. This cannot be said of the decree of the Council of People's Commissars with the aforementioned passage referring to the partitions of Poland. Although Stalin's article contains a number of misrepresentations and lies, it can paradoxically constitute a credible source depicting the actual intentions of the Bolsheviks towards the nations of the former Russian Empire.

${ }^{24}$ Ibid., p. 177.

25 W. Sukiennicki, "Przyczyny i początek wojny polsko-sowieckiej 1919-1921," part 2, Bellona, 1963, fasc. 3-4, p. 154.

26 J. W. Stalin, op. cit., pp. 177, 178.

27 Ibid., p. 178. 
On 19 October 1918 at a rally in Petrograd, Trotsky spoke in a similar spirit as the People's Commissioner for Nationalities. He stated, among other things: "The historic hour has come. There comes a time when our brothers in Lithuania, Poland, Ukraine and, I hope, also Finland, will come together under the banner of the RSFSR." ${ }^{28}$

The thoughts expressed by Soviet politicians at the time were more than just cocky boasts, propaganda platitudes or unfounded threats. The subsequent months would prove that the Bolsheviks implemented these seemingly utopian fantasies, often successfully. They did so by the force of the Red Army bayonets reinforced by the power of ideology and propaganda.

In mid-November 1918, the rebirth of independent Poland became a fact. Released after 16 months of imprisonment at the Magdeburg fortress, Józef Piłsudski arrived in Warsaw, where the Regency Council bestowed upon him military power and the highest command and entrusted him with the mission of forming a national government. The coalition governments and other states were notified by telegrams on the existence of a Polish state. On 18 November, a national government was formed, led by socialist Jędrzej Moraczewski. The newly formed state had no established borders, meaning that armed and diplomatic struggle for their exact location would endure for a long time.

Also within the country, regaining its unity and struggling with the legacy of the partitions and post-war poverty, peace would long not be restored. The downfall of the World War was a period of significant increase in social radicalism in many European countries. The councils of workers' delegates forming on Polish soil and the manifestations under the red banners were associated explicitly (although not always strictly, since both socialists recognising Poland's independence and communists striving to make it a "republic of councils" were present on the political scene) with the Eastern models.

The instability and social unrest were favourable to the Bolsheviks, who skilfully fuelled them with the intention of transferring the "flame of revolution" to the West. A conflict between sovereign Poland and red Russia was bound to occur. The armed clashes which began in early 1919 simultaneously sparked the nearly two-year-long Polish-Soviet War. Poland had to confront not only the guns of the Red Army, but also the powerful pressure of the Soviet agitation and propaganda apparatus (agit-prop). The fight took place on military, political and diplomatic levels, but it was also a psychological, ideological and propagandist war. The reborn Polish state was confronted with a propaganda state born after the October coup, as Bolshevik Russia was aptly described by an American historian. ${ }^{29}$

The propagandist war was imposed on Poland even before the beginning of the armed clashes. The article "Partition Wall" discussed above may be regarded

28 Quote after: W. Sukiennicki, op. cit., part 2, p. 152.

${ }^{29}$ P. Kenez, The Birth of the Propaganda State. Soviet Methods of Mass Mobilization, 1917-1929, Cambridge-London-New York, 1985. 
as its first manifestation. The subsequent offensive of Soviet Russia, conducted by means of political weapons, i.e. violent agitation and propaganda directed against "white" Poles and in favour of "Soviet Poland," significantly boosted military action and the political and diplomatic campaign.

This psychological war, conducted at the level of public awareness, was aimed at influencing human minds, shaping attitudes and changing the way of thinking. In this flood of anti-Polish propaganda from the period of the 1919-1920 war, one can distinguish messages referring to the issue of Poland's independence and the rebirth of the Polish state. The agitational messages did not always relate to the subject directly, sometimes it was expressed by means of symbols (such as the image of the White Eagle serving as the Polish coat of arms), but the independent Republic was always an object of disdain and attempts were made to convince the audience that "bourgeois" Poland was not in fact a sovereign state. According to this line of reasoning, true freedom was to be brought to Polish workers and peasants on Red Army bayonets. The considerable financial resources allocated to propaganda in war-ravaged and starving Russia seemed to be well invested from the point of view of those who ruled the country. The Bolsheviks were counting on the support of the "conscious" Polish population and believed that a revolution would break out in Poland. This was supposed to lead to the establishment of "red Poland": a state (as politicians and agitators proclaimed) friendly towards Soviet Russia... and strictly subordinated to it.

In reality, however, there was the Republic of Poland, a country considered hostile from the beginning, against which the RSFSR waged war. Poland was described in speeches and propaganda texts with epithets considered offensive by the Bolsheviks. It was therefore treated with contempt, defined as "white," "noble," "lord," "bourgeois," "imperialist." 30

The Bolsheviks attributed great importance to the notion of Independent Poland. This term was usually accompanied with quotation marks, which reflected their attitude towards the reborn Republic of Poland. Precedence in this matter should be attributed to the Polish communists residing in the territories of the RSFSR, who, almost immediately after Poland's declaration of independence, began to disavow the newly created state. Accusations were manifold; the so-called Independent Poland was claimed to be "a servant of the international counter-revolution," a puppet state of the Entente government. These allegations (previously present mainly in the Polish communist press) began to be disseminated by Russian journalists and agitators during the already ongoing Polish-Soviet War, when anti-Polish propaganda intensified in Soviet Russia. Poland was portrayed as a failed state, dependent in every respect on the West, and at the same time as an invasive, imperialist force. These latter accusations referred to the still undetermined Polish borders in the east. The Polish side was accused of seeking

${ }^{30}$ Cf.: A. J. Leinwand, Czerwonym młotem..., passim. 
to restore the pre-1772 shape of its territory (i.e. from before the partitions), which reached much further to the east. In concert with the Polish communists, the subject of Polish "independence" was ridiculed by the Bolsheviks; Poland was accused of oppressing its own workers and peasants, as well as the Ukrainian, Belarusian and Jewish population. It was repeatedly asserted that in the so-called Independent Poland the workers were more oppressed and that there was greater poverty and injustice than during the partitions. At the same time, Lenin, and other politicians and propagandists after him, repeatedly emphasised that they recognised the independence of Poland. It was supposed, however, to be independence in the Soviet fashion.

It should be noted that the Soviet propaganda message varied according to rapidly changing circumstances and its recipients. The Soviets adopted different styles when addressing their own civilian population, soldiers (Russian or Polish), foreign recipients (e.g. governments or residents of Poland, England and France), etc. One example can be the so-called Soviet peace offensive, which was carried out at the turn of 1919 and 1920 on a great scale and on various levels. In his diplomatic notes addressed abroad, the People's Commissar for Foreign Affairs, Gieorgiy Chicherin, asserted "a strong desire to end all conflicts with Poland."31

A month later, the Council of People's Commissars addressed the government and the Polish people with a statement reiterating the peace offer. The message of this text, although full of propaganda slogans, is of a serious nature, and not just a propaganda leaflet. Lenin, Trotsky and Chicherin, who were signed underneath, claimed that the RSFSR "had recognised and does recognise completely and unconditionally the independence and sovereignty of the Republic of Poland," and that this recognition was based "...on the unshakeable principle of national self-determination." ${ }^{32}$ Practice proved that the Bolsheviks treated the notion of "self-determination" instrumentally; it was one of their propaganda tricks.

The campaign for the conclusion of peace with Poland was, however, dominated by appeals (addressed to both Russians and Western European societies) characterised by militancy, with a message clearly and violently propagating the ideas of revolution. Such was the nature of, for instance, the statements and texts signed by the Third International. In February 1920, the periodical Kommunisticheskiy Internatsional published an article by Grigory Zinoviev entitled "To the workers of all countries. On the Polish issue." ${ }^{33}$

This text is very characteristic and, what is important, it was signed by the Chairman of the Comintern's Executive Committee, therefore it should be treated as the official position of the Third International, and thus as the official position of

${ }^{31}$ Note of 22 December 1919 addressed to the Polish Prime Minister Leopold Skulski; Polish translation: Powstanie II Rzeczypospolitej..., doc. 270, p. 536.

32 Declaration of 28 January 1920 in: ibid., doc. 272, p. 539.

33 Kommunisticheskiy Internatsional 1920, no. 20, cols. 1393-1398; text dated 17 II 1920; (the title and quotes in my translation). 
the authorities of the RSFSR. Worth emphasising is the elaboration on the issue of Poland's independence. Here is how it was described to "workers of all states": "Independent Poland was born not in the wake of the rise of the Polish masses. [...] The ruling classes of landowners and capitalists in Poland have exploited the banner of independence so as to bargain for their own influence during the war with the three governments with whom they were tied throughout history. [...] Poland obtained a certain independence only because imperialism had collapsed in Russia and Germany under the pressure of the people's masses."

As one can see, Polish matters were depicted here in a completely different light than in the communications addressed to the Poles. The explicit or somewhat veiled (depending on the needs) denunciation of Poland's independence was a recurring theme in Soviet propaganda, especially in its variety directed to its own society and towards the West.

As mentioned above, from the beginning of the armed conflict with Poland, Soviet politicians and propagandists had been accusing their opponents of imperialist aspirations. ${ }^{34}$ These accusations intensified in the spring of 1920 and reached their climax in the summer, in the decisive phase of the war.

After the winter of 1919/1920, when both sides of the conflict were conducting diplomatic activities and, simultaneously, intensive preparations for an armed resolution, the eastern offensive of the Polish Army (known as the Kiev Expedition) began on 25 April, in consultation with the allied Ukrainian forces of Ataman Semen Petlura. The attack was led by the Chief of the Polish State and the Commander-in-Chief, Józef Piłsudski. He knew Russia well and believed that any strong Russian state, regardless of its political colour, posed a serious threat to Poland. As he was carefully observing the Bolsheviks' progress towards the West and their war preparations in parallel with a "peaceful" diplomatic campaign, he decided to initiate a pre-emptive action. The political objective of the Kiev Expedition was the restitution of Transnistrian Ukraine allied with Poland, while the military goal was to eliminate the Bolshevik forces operating in the area. ${ }^{35}$

Four years after these events, Marshal Piłsudski himself explained the motives of his actions in the following manner: "It was an undeniable fact that [...] Soviet Russia waged a war with us with the ambition of imposing on us, Poles, a system identical to theirs, the Soviet system that is, and baptised their goal as a revolution from the outside. The fact that this was the purpose of the war was very well known to me, and that is why I declare straight away that I personally conducted the war for no other reason than to ensure that this revolution from the outside

34 This was a well-thought-out policy of informing, or more precisely: disinformation, about Polish-Soviet relations. It followed the recommendations by Chicherin, who, in a note to Lenin, wrote in mid-February 1920: "If war breaks out, it is absolutely necessary that the Polish government be held entirely responsible" (after: A. Nowak, Polska i trzy Rosje. Studium polityki wschodniej Józefa Piłsudskiego [do kwietnia 1920 roku], Kraków, 2001, p. 508).

35 W. Suleja, Józef Piłsudski, Wrocław, 1995, p. 221. 
was not brought to us by Soviet bayonets. Poland has been at war with the Soviets since 1918, even though it was a year when Poland had begun to live independently only over the two final two months.

I had also set myself back in 1918, independently of anyone, a clear goal for the war with the Soviets. Namely, I decided that all forces should be exerted, even as far away as possible from the places where new life was hatching or being forged, to subvert all attempts and temptations to impose on us, once again, a life strange to us, a life not governed by ourselves." 36

The response of Soviet propaganda to Piłsudski's offensive was a flood of leaflets, drawings, posters, press publications and political speeches at numerous rallies and meetings, with the campaign gaining momentum since the end of April. Another tool used in the psychological war with Poland were agitation trains with propaganda materials and "instructors" on board that were travelling the country with the task of educating and inciting the population. Over time, numerous films, poems and songs condemning the "white Poles" were also written.

During that time, one could witness the intricacies of Soviet agit-prop in the swift adaptation of the propaganda message to new circumstances. The crimes of "Polish masters" and Polish imperialism were repeatedly mentioned and written about this entire time, along with assurances of respecting Poland's independence and lack of hostile intents towards it. Soviet propaganda consistently depicted the Kiev Expedition as a Polish attack on Russia. "They have invaded us," wrote Nikolai Bukharin on 27 April; he was probably the first to do so, and the phrase had become binding from then on. Soviet politicians and propagandists presented the Polish offensive in Ukraine as if it was an "assault," and an "assault" on Russia at that. The recipients of the propaganda campaign could get the impression that the Polish Army was marching towards Moscow. It was a measure of deeper political and psychological significance, used as deliberately as possible to unite and motivate the entire society to fight. In response to Piłsudski's offensive, a nationwide alarm was raised because of the alleged threat to Russia. It was in the spring of 1920 that a significant change in the Soviet propaganda communication took place. The war was portrayed not only as a class struggle (as was the case since the Bolshevik coup in relation to the battles fought by Russia on many fronts), but also as a national one. They began to refer to the notion of Russia in its traditional and historical sense, as well as to patriotic feelings, which shortly beforehand had seemed unthinkable. This tendency would intensify and become evident in the various "products" of the Soviet anti-Polish propaganda. ${ }^{37}$

The first major manifestation of this new approach was the proclamation To All Workers, Peasants and Honourable Citizens of Russia! published on 29 April by the All-Russian Central Executive Committee (VTsIK) and the Council of

\footnotetext{
36 J. Piłsudski, Pisma zbiorowe, vol. 7, Warszawa, 1937, pp. 146, 147.

37 Cf.: A. J. Leinwand, Czerwonym młotem..., pp. 99-100.
} 
People's Commissars of the RSFSR. ${ }^{38}$ Signed by the chairman of the VTsIK, Mikhail Kalinin, as well as Lenin, Chicherin, Trotsky and People's Justice Commissar Dmitry Kursky, it expressed the official position of the Soviet authorities. The lengthy document draws attention to the perception of Poland's independence. The authors of the proclamation assert its recognition in several places, but the further elaborations on this issue, although present in the propaganda slogans, clearly show the true intentions of the Soviet. After calls to fight the "Polish masters" and assurances of triumph over them, it is also stated: "After we have routed Pilsudski's bands, the independence of Poland will still remain inviolable for us. With the Polish proletariat and the Polish peasantry, who will become absolute masters in their country, we shall without difficulty form a fraternal alliance. Only the gentry and bourgeoisie who are our common enemies keep us apart." Among the slogans ending the proclamation were, among others:

\section{"Long live independent workers' and peasants' Poland!"}

or

\section{"Long live the Soviet Ukraine! Long live Soviet Russia!"39}

Poland was therefore granted the right to independence, but only the victorious workers and peasants were to enjoy it. In other words, it was meant to be independence under a red (revolutionary) flag rather than a white and red one (the colours of the Polish national flag symbolising the Reaction, according to the Bolsheviks). What is more, it was supposed to be sovereignty, but in a "fraternal relationship" with the Soviet Republic. The upcoming months were to prove that these words were not just propaganda platitudes, boasts and threats, as the Bolsheviks truly attempted to put their programme into practice. Ukraine was also expected by the propagandists to become a Soviet state, just like Russia.

The text ended with one more noteworthy slogan: "Let us say to the proletarians and peasants of Poland: For our freedom and yours!" 40 This statement has already been mentioned above. After some modification it turned out useful also for the Bolsheviks. Interestingly, both the cited slogan and comments on the "fraternal union" between Poland and Russia were first included in the proclamation of the Provisional Government in March 1917. We can see here the variety of means, subjects and motifs that Soviet propagandists used to resort to in order to reach the largest and most diverse audience possible with their message.

On 1 May, the newspaper Izvestia featured, on its front page, one of the most important propaganda texts of the 1920 war. This was Trotsky's proclamation

${ }^{38}$ For the text in its original language, cf.: Dokumenty $i$ materiały do historii stosunków polsko-radzieckich [hereinafter: DiM], vol. 3, kwiecień 1920 - marzec 1921, Warszawa, 1964, doc. 9.

39 Ibid., p. 19.

40 Ibid. 
(also issued in the form of leaflets) entitled Death to the Polish Bourgeoisie. ${ }^{41}$ It reads, among other things, that "nowhere in the world is there a bourgeoisie greedier, more corrupt, insolent, frivolous and criminal than the gentrified bourgeoisie of Poland." The Marxist arsenal of epithets directed at class enemies was complemented here with the colours of traditional Russian nationalism. During the PolishSoviet War such combinations became commonplace. The Bolsheviks were right to assume that propaganda addressed to the mass audience would be more accessible, and thus more effective, should it exploit national rather than class arguments.

The proclamation ends with the following sentences, printed in bold:

[...] we all, as one man, will swear to defend the Soviet Republic from the unbridled Polish bands. The rebuff we shall give will be merciless and irresistible. Death to the Polish bourgeoisie. Over its corpse we shall conclude a fraternal alliance with workers' and peasants' Poland.

The motif of "the corpse of White Poland" also appeared in one of the speeches by Trotsky, and then in the famous order of July 1920, which is going to be discussed below. Such expressive images characteristic of war propaganda were intended to unambiguously encourage the recipients to battle with the hated enemy.

It was probably then, after 25 April 1920, that we witnessed the birth of a phenomenon that could be described as "Soviet patriotism." It was extremely useful to the leaders at the Kremlin, as it conferred new quality on the rejected notions of traditional patriotism and thus "rehabilitated" them. The new concept created by ideologists and propagandists had a practical application. It allowed, for example, the fight for Soviet Ukraine or Belarus not only in the name of internationalism, but also in the name of traditionally understood patriotism. This sociotechnical trick made it possible to lure many people who had so far been intransigent towards the new system to the side of Bolshevik Russia. Soviet agitation and propaganda skilfully pinpointed the enemy. In view of the perspective, or even the necessity, of defending Russia against the "White Poles" (as the propagandists presented it), ideological divisions seemed to blur. In the minds of Russian patriots, the idea of fighting in defence of the "one and indivisible" was being born.

The most spectacular example of such an attitude was the engagement of the Russian general Alexei Bruselov and other higher commanders of the Tsarist army in the war with Poland. In speeches and propaganda texts, Soviet politicians could now suggest a model to follow. In the name of a higher necessity, which, according to the authors of the propaganda message, was to defend the independence of the Russian nation, people of very different convictions were now uniting. ${ }^{42}$

41 The quotes are from a copy of a leaflet preserved in the collection of the Historical Library in Moscow (print, 1 p.).

${ }^{42}$ It is worth citing the remarks on this subject made by Tadeusz Teslar, the author of a classic book from the interwar period devoted to the Bolshevik propaganda with regard to Poland. He stated 
The period of the greatest successes of Polish troops on the front and the seizure of Kiev (8 May 1920) saw the emergence of a veritable "propaganda storm" directed against Poland. Rallies condemning the "Polish invasion" of Soviet Russia (sic!) were held in cities of all Soviet republics.

On 18 May, the Executive Committee of the Communist International issued the proclamation To the Proletarians of All Countries ${ }^{43}$ presenting a picture of the ongoing war intended for recipients in the West. This message was part of a largescale campaign (of a global scope, without exaggeration) of the RSFSR. Through its emissaries and agents, the Soviet government campaigned for the benefit of Bolshevik Russia in numerous countries. ${ }^{44}$

Let us quote just one passage from the extensive Comintern proclamation:

Workers of all coalition countries! Take to the streets, organise demonstrations and strikes under the slogan Down with supporting counter-revolutionary Poland! The coalition should keep its hounds-Polish capitalists and landowners-at leash and make a fair peace with Soviet Russia.

Certain motifs and images were recurring in various types of propaganda materials. The list of slogans used to decorate the agitational train named after Lenin included the following text: "White Poland is a rabid hound of the bourgeoisie. Chain her up!" 45 And in early June, the front page of Pravda once carried the following appeal: "The rabid dogs of Polish imperialism must be destroyed!" 46

The image of a rabid dog symbolising Poland was also placed on agitational posters. The heated atmosphere of that time, and anti-Polish emotions, skilfully fuelled by the Bolshevik leadership, are very aptly reflected in two famous posters by Victor Deni (Denisov, 1893-1946).

The first one depicts an enraged dog with a copious moustache in the style worn by the Polish nobility in ancient times, with a feathered cap, and a crowned eagle (coat of arms of Poland) on the medallion hanging around the animal's neck. The inscriptions in Russian proclaim: “The most honourable Poland. The Entente's

that "one great propaganda trick employed by Trotsky was his announcement of the declaration made by Brusilov, the former Tsarist general, who offered his services to the Bolsheviks in the war against Poland. This was to prove that the war between Russia and Poland was considered a national war in Russia, a popular war. It was meant to assert before the world that the Soviet system had been recognised by Russian patriots as a form of government that would guarantee the protection of Russia's national interests against external enemies". (T. Teslar, Propaganda bolszewicka podczas wojny polsko-rosyjskiej 1920 roku, Warszawa, 1938, p. 126).

43 The proclamation was published in the periodical Kommunisticheskiy Internatsional of 14 June 1920, cols. 1861-1864; Polish translation: DiM, vol. 3, doc. 30.

${ }^{44}$ Cf.: E. M. Carroll, Soviet Communism and Western Opinion 1919-1921, Chapel Hill, 1965.

45 A. J. Leinwand, Sztuka w stużbie utopii. O funkcjach politycznych i propagandowych sztuk plastycznych w Rosji Radzieckiej 1917-1922, Warszawa, 1998, p. 146.

46 Pravda of 4 VI 1920. 
last dog," and below: "The Polish property-owners want to squash the workers' and peasants' Russia. Death to the noble lords!"

The second, twin poster by the same author can also be classified as a "zoological" composition. It is a lithography titled Pig Trained in Paris, depicting a fattened animal sitting in the hands of a French general. The pig is wearing a krakuska cap with an inscription in white on its rim: "The most honourable Poland" (as in the case of the dog). In its front hoof, the moustached animal is holding a document bearing the inscription " 1772 borders" (i.e. the pre-partition Commonwealth borders), and it is drooling all over it. This scene was intended to show the audience, in an overly illustrative manner, the unrestrained territorial appetites of Poland and its total dependence on France. It was suggested that Poland, despite its "imperialist" aspirations, was in fact weak and passive. Such an opponent should not arouse fear, only contempt. ${ }^{47}$

The Bolshevik Russia had many enemies, both abroad and internally, who would combat the new regime on the frontlines of civil war. The latter included, among others, the armed forces of the so-called White Russia, commanded in various periods after 1917 by Admiral Alexander Kolchak and generals Anton Denikin and Pyotr Wrangel. In late spring 1920, the Poles found themselves at the top of the hierarchy of enemies of the Soviet republic. This was expressed in a very simple, clear and concise manner by Vladimir Mayakovsky (1893-1930) in his captions to one of the "Rosta windows." 48 When addressing "his comrades workers and peasants, the young, the old and the children" the poet reminded them that their "greatest enemies" were: "1. Piłsudski and the tribe of masters, coming to restore autocracy," and only in the second place was "General Wrangel, the headsman of the South." In the conclusion, the author calls on everyone to fight to "demonstrate strength to both the master and the baron." 49

In early June the Polish front was broken by Budyonny's cavalry, leading to the retreat of the Polish Army from Ukraine. On 10 June the Polish troops left Kiev. In response to the new situation on the front, the Bolsheviks adjusted their propaganda message.

At the time of the Poles' retreat in Ukraine, the RSFSR authorities conducted an "explanatory campaign," mainly to shape the opinions of the West, but also

47 Copies of both posters can be found, among others, in the iconographic collections of the Russian State Library in Moscow; for reproductions see: A. J. Leinwand, Czerwonym młotem..., Fig. 13 and 14.

48 ROSTA, the Russian Telegraph Agency established in September 1918 as the "central Soviet information body for the entire RSFSR" (cf: Dekrety Sovetskoy vlasti, Moskva, 1964, pp. 296297). An important area of Rosta's activity was its work in the field of culture and education, including the publication of agitational posters, the famous "windows of satire." Handmade and primitively reproduced posters were placed on display windows, hence their name (see: S. White, The Bolshevik Poster, New Haven-London, 1998, pp. 65-89).

49 V. Mayakovsky, Polnoe sobranie sochinenii, vol. 3, Moskva, 1957, p. 103. 
for internal use. Lies about the alleged destruction and arson (including Orthodox churches) supposedly committed by the Poles leaving Kiev were spread. This fictitious news was included in a note sent on 11 June by the governments of Soviet Russia and Ukraine to those of Western countries. The texts expressed outrage at the unprecedented barbarity and cruelty of Poles, thus portraying the events in a positive light for Bolshevik Russia. The author of the note, Chicherin, expressed the holy indignation of a humanist at the alleged destruction of the Dormition Cathedral in Vladimir..$^{50}$ The world was given an unequivocally negative image of a Polish barbarian and a positive image of a cultured Russian (Bolshevik). Such a message was designed to discredit Poland in the eyes of the West and to convince cultured Europeans (even if critical of Bolshevism) of the peaceful and human nature of Soviet Russia. It was pointed out that supporting "imperialist Poland" would lead to similar crimes, urging the West to cease providing it with any assistance.

Basically the same content, but expressed in slogans: briefly and much more bluntly, was disseminated inside the country. On 13 June, in a propaganda text published on the front page, the newspaper Pravda was crying out: "The torturers are still alive. Death to the torturers!" These appeals referred to the "Polish White Guard," which allegedly "blew up Kiev after depriving it of light, water, railways and bridges, cultural monuments and livelihoods." ${ }^{\text {1 }}$ On the same day Izvestia's front page carried an article by Lev Kamenev entitled "The Enemy Is Vile, Despicable and Cruel." 52

By the end of June, the intensive preparations for the Red Army's counteroffensive on the Western Front were concluded. The activities also covered the political and propagandistic aspect of the planned military operation. On 2 July 1920, the commander of the Western Front, Mikhail Tukhachevsky (1893-1937), issued order no. 1423 in Smolensk, addressed to the commanders of individual armies. It was to be read in all units on the day before the attack began.

There were at least two published versions of this order, both of which differed from the original one. ${ }^{53}$ Here are the most representative fragments of the translation of the text printed in the newspaper Krasnoarmeets on the day of the launch of the great Bolshevik offensive: "TO THE WEST! An order to the troops of the Western Front. Soldiers of the Red Army! The time of reckoning has come! Our troops across the front are now on the offensive. Hundreds of thousands of soldiers have prepared themselves to deliver a terrible blow to the enemy. The great duel

${ }^{50}$ For the text of the note in Russian, see: DiM, vol. 3, doc. 44. For a clarification of false information contained in the note, see: A. J. Leinwand, Czerwonym młotem..., pp. 126-127.

${ }^{51}$ Pravda of 13 VI 1920.

52 Izvestia of 13 VI 1920.

53 All indications are that the archive contained the first draft version of the order and that the text (without any cuts or stylistic corrections) was published in an annex to book by N. Kakurin, V. Melikov, Grazhdanskaya vojna v Rossii: Vojna s belopolyakami, Moskva-St. Petersburg, 2002, pp. 669-670. 
will determine the fate of the war between the Russian nation and the Polish rapists. The army of the Red Banner and the army of the predatory White Eagle face each other in mortal combat. [...] Before the offensive, fill your hearts with anger and ruthlessness! Avenge the burnt down Borisov, the disgraced Kiev, the plundered Polotsk! Take revenge for all the times the Polish nobility laughed in the face of revolution! Over the dead body of White Poland shines the road to world-wide conflagration. On our bayonets we shall bring happiness and peace to toiling humanity! To the West! [...] On to Vilna, Minsk and Warsaw! March!"54

The frontline newspaper published the most concise and the most unambiguous version of this order. The message addressed to the soldiers was devoid of nuances and, in fact, honest. It embodied a sense of triumph after the victories of the Bolsheviks over Kolchak and Denikin and a desire for revenge against the "white Poles." The order encouraged the Red Army to fight and clearly indicated the goal, which was to conquer Europe and then the world. There are no slogans here about peace, unlike in Chicherin's note for the Western audiences.

There was also a more extensive version of Tukhachevsky's order (compared to the one published by Krasnoarmeets). In this variant the following sentence should be noted: "In the blood of the defeated Polish army we will drown the criminal government of Piłsudski." 55

This order was undoubtedly the most important act of Bolshevik propaganda in the entire period of the war with Poland. It understandably exerted a different influence on Soviet soldiers then on the Polish public opinion (i.e. inconsistent with the intentions of Soviet politicians and propagandists). ${ }^{56}$

Particularly noteworthy are two motifs that were included in the July order: the "predatory white eagle" and "dead body of White Poland." The Bolsheviks used these images with predilection in their anti-Polish wartime propaganda, in both verbal (spoken and printed) and visual communication. An example of the former method of using the motif of the Polish eagle is the proclamation of the Military and Revolutionary Council of the Western Front, announced on 12 July 1920 in Smolensk with the signatures of Tukhachevsky and Józef Unszlicht (1879-1939).

${ }^{54}$ Krasnoarmeets Yezhednevnaya gazeta Politotdela Revvoyensoveta 16-y armii, no. 326 of 4 VII 1920, p. 1.

55 Quote after: T. Teslar, Propaganda bolszewicka..., p. 212. The version of the order published by this author probably comes from the newspaper Krasnaya Zvezda of 11 July 1920.

56 Tadeusz Teslar stressed the political importance of Tukhachevsky's order and the fact that it constituted "a perfect model from the propagandistic and agitational point of view." At the same time, however, it "revealed, due to the lack of diplomatic tactics, the discrepancies between [...] the policy of the Russian state and [...] the revolutionary aspirations of the communist party seeking clear support for its influence in Poland." "The announcement of Russia's retaliation against Poland," noted the same author, "stimulated the Polish nation to self-defence and knightly pride. [...] Tukhachevsky's sincerity in such a hypocritically demonstrated display of Polonophobia led to a political advantage for Poles rather than Russians, regardless of the class interests of the proletariat." (Propaganda bolszewicka..., pp. 213-214). 
The text addressed to the "working masses of liberated Belarus" begins as follows: "Peasants and workers of Belarus! The claws of the mortally wounded white Polish eagle are releasing the tormented body of the Belarusian nation. ${ }^{57}$

The second example is a poster that could serve as an illustration to the above words. Printed in a Polish communist publishing house in Kiev, it depicts a white eagle struck down by the blows of hammers of a worker and a peasant. The text underneath the lithography reads that "in the clutches of the white eagle moaned the proletariat of Poland, Belarus and Ukraine. [...] Under the blows of workers' hammers, the Poland of capitalists and gendarmes collapses into ruins, the white eagle perishes. Under the red flag a new socialist Poland is born: THE POLISH SOCIALIST REPUBLIC OF COUNCILS [...]." ${ }^{n 8}$

The victory of the Polish Army in the Battle of Warsaw (14-16 August 1920) and Poland's subsequent successes in the war with Soviet Russia in the following weeks forcing the Red Army to retreat and ending in a ceasefire (18/19 October 1920) — in other words, the end of military operations_-did not put an end to the propaganda war.

On 18 March 1921 a peace treaty was concluded in Riga between Poland, Russia and Ukraine. Article 5 of this act stated that "each of the Contracting Parties mutually undertakes to respect in every way the political sovereignty of the other Party, to abstain from interference in its internal affairs, and particularly to refrain from all agitation, propaganda or interference of any kind, and not to encourage any such movement [...]." 59

However, the Soviet authorities did not intend to respect the commitments they had signed. They continued the propaganda war with Poland, although in a slightly different character and not as violently as during the wartime. The continued anti-Polish activities resulted from the fundamental fact that the Bolsheviks did not intend to accept the existence of an independent Polish state.

Following the Treaty of Riga, Polish communists were used to a greater extent than before for propaganda actions against Poland. They were completely subordinated to Moscow and, at the request of the headquarters, they conducted, among others, agitation among Polish prisoners of war. The Bolsheviks hoped that the appropriately indoctrinated Polish soldiers, after their release from the camps and return to Poland, would act as agitators and prepare grounds for the Sovietisation of the country.

One meaningful testimony to such intentions is the proclamation published in March 1921 in Polish by the Third International, entitled See You in Red Poland! ${ }^{60}$

57 Quote after: T. Teslar, Propaganda bolszewicka..., p. 217.

58 B. S. Butnik-Siversky, Sovetskiy plakat epokhi grazhdanskoy voyny, Moskva, 1960, p. 620.

59 Riga Peace Treaty, Article 5 ("Respect for Sovereignty"), quote after: K. W. Kumaniecki, Odbudowa..., p. 530.

${ }^{60} \mathrm{I}$ am using a copy of the leaflet (print) from the Bibliothèque de Documentation Inernationale Contemporaine in Nanterre, GF $\Delta 14$ Rès 17; this is the source of the quotes. 
It stated, among other things, that "a Polish labourer has it worse now in this 'independent' servant of the Entente than in the times of the Tsar."

And here is the end of the proclamation:

Remember this, comrades, when you return to Poland, when you see for yourselves that the situation is increasingly hopeless, that the only rescue is in revolution, in the dictatorship of the working people.

Know then that we shall come to your aid! And no one will be able to take power back once it has been seized by the people of Soviet Poland! [...]

SEE YOU IN RED, SOCIALIST POLAND, IN A JOYFUL POLAND, TRULY FREE OF ALL EXPLOITERS OF THE WORLD!

Long live the Polish Socialist Republic of Workers' Councils of all cities and villages.

Long live the Commune!

Propaganda texts and their "wishful thinking" are rarely taken seriously. However, the Soviet propaganda policy, and especially some of its manifestations (such as the above proclamation) deserve attention. The text freely expresses the true intentions of the Soviet authorities. The imperial goals of Soviet Russia, which could not be achieved in 1920, were achieved in 1939 and 1944/1945. Just as the authors of See You in Red Poland! had announced it, or more precisely: as the Soviet leaders had planned.

The Soviet propaganda communications from the first period of the existence of both the new Russian state (RSFSR) and the reborn Republic of Poland contain an unequivocal attitude towards Polish independence. The "agit-prop" communiqués, however full of false information and deliberately disseminated lies, paradoxically constitute a credible testimony to the real intentions of the Bolsheviks. This cannot be said of official notes and diplomatic documents in which-although not always-attempts were made to at least keep up appearances with regard to the recognition of the sovereignty of Poland by the RSFSR. But even these official enunciations were ever so suggestive in informing about "Polish imperialism" and the troublesome behaviour and "barbarism" of the Polish army, which implied that the independent Polish state was a source of constant problems and a threat to peace. All the more so as the "peaceful aspirations" of Bolshevik Russia were simultaneously emphasised and publicised. Thus, the recipients of Soviet propaganda could easily conclude that the most beneficial solution for peaceful order in Europe would be the non-existence of sovereign Poland.

The dissatisfaction with the independence of the Polish Republic was manifested not only in the immediate Bolshevik agitation frontally attacking the enemy, but also in the suppression of Polish symbols, such as the white eagle.

This rhetoric returned in the autumn of 1939 with the outbreak of a new world war which began with the attack on Poland in the west (1 September by Germany) and in the east (17 September by Russia). On 1 November, during a session of the USSR Supreme Council, the chairman of the Soviet Council of 
People's Commissars, Vyacheslav Molotov (1890-1986), in a speech devoted to the international situation, stated, inter alia, that "a brief assault on Poland by the German army first, and then by the Red Army, proved sufficient so that nothing would remain of this miserable creation of the Treaty of Versailles." 61 This statement reflects the attitude of Soviet Russia towards both the existence of an independent Polish state and the Versailles system. These were the arrangements ending the First World War, with which the Russians (and the Germans alike) never came to terms and which they attempted to undermine from the very beginning. They succeeded after twenty years.

The famous words of Commissar Molotov constitute a sui generis summary of the matters discussed here. A Soviet poster from September 1939 could also act as a summary expressed in visual language and, at the same time, an illustration of the quoted statement. It depicts a powerful Red Armist in a helmet with a five-pointed star who is piercing the neck of the Polish eagle with a bayonet. ${ }^{62}$ This comes as a sort of culmination of the eagle theme in the Bolshevik anti-Polish propaganda, with reference to motifs from 1920, such as the poster entitled Finis Poloniae. ${ }^{63}$

In 1939, just like twenty years earlier during the Polish-Bolshevik war, Soviet politicians and propagandists proclaimed the end of independent Poland.

\section{Abstract}

With an increasingly evident perspective of a global armed conflict, the turn of the $19^{\text {th }}$ and $20^{\text {th }}$ centuries revived the aspirations of the subjugated nations of Europe. Among the peoples in Central and Eastern Europe awaiting an opportunity to effectively claim their rights were the Poles, who had been deprived of their own state since the end of the $18^{\text {th }}$ century as a result of partitions carried out by neighbouring powers: Russia, Prussia and Austria.

The outbreak of war and the spread of armed conflict created a completely new set of circumstances. From the very beginning, the Polish lands became an area of activity of the armies of the partitioning states, which meant that the Russians, Austrians and Germans had to begin to reckon with the Polish opinion. Their declarations and proclamations, with more or less tangible promises, were aimed at gaining the favour of the Poles. By the end of the Great War, the President of the United States was also in favour of the creation of an independent Polish state. The issue of Poland's independence, now raised in the international arena, became a factor that could no longer be ignored.

The Bolsheviks, who had been governing in Russia since the military coup in November 1917, were also forced to express their opinion on this issue. Their decrees proclaiming the right of nations to self-determination were full of pompous slogans, which, however, were

${ }^{61}$ Quote after: W. Materski, Na widecie..., p. 570.

${ }^{62}$ For a reproduction of the poster, see: W. Materski, Tarcza Europy. Stosunki polsko-sowieckie 1918-1939, Warszawa, 1994.

63 The poster from 1920 was designed by Fiks, see: B. Butnik-Siversky, Sovetskiy plakat..., cat. 913. "Finis Poloniae!" is a phrase attributed to Tadeusz Kościuszko after his defeat at the Battle of Maciejowice during the 1794 Uprising. 
completely at odds with practice. They adopted their position on the Polish issue after a long delay, and when the establishment of an independent Poland in November 1918 became a fact, Lenin, Stalin and Trotsky did not hide their hostility towards the newly formed state with its "bourgeois-nationalist" government. They counted on the "socialist face of self-determination," i.e. the outbreak of the revolution in Poland. These visions were disseminated in speeches and texts of Bolshevik leaders and in other propaganda "products."

Soviet anti-Polish propaganda significantly intensified after the start of the Polish-Soviet armed struggle. The war, which lasted almost two years, was characterised by its ideological and propaganda aspect. Sovereign Poland was to be buried not only manu militari, but also by means of violent agitation and propaganda expressed in word, image and sound in journalism, poetry, songs, leaflets, caricatures and posters printed in thousands of copies.

Various methods were used, including disavowing the Polish leaders (especially the Chief of State, Józef Piłsudski), ridiculing Polish national symbols (the white and red flag and the coat of arms of Poland, the white eagle), convincing the West that Poland and Poles were posing a threat to peace. The mass Soviet propaganda was supposed to justify the march of the Red Army to the west and to convince the recipients of the propaganda message that the most beneficial solution for peaceful order in Europe would be the non-existence of sovereign Poland.

\section{Bibliography:}

\section{Compilations}

Achmatowicz A., Polityka Rosji w kwestii polskiej w pierwszym roku Wielkiej Wojny 1914-1915, Warszawa, 2003.

Carroll E. M., Soviet Communism and Western Opinion 1919-1921, Chapel Hill, 1965.

Kakurin N., Melikov V., Grazhdanskaya vojna v Rossii: Vojna s belopolyakami, MoskvaSt. Petersburg, 2002.

Kenez P., The Birth of the Propaganda State. Soviet Methods of Mass Mobilization, 1917-1929, Cambridge-London-New York, 1985.

Kołakowski L., Main currents of Marxism. Its rise, growth, and dissolution, vol. II, The Golden Age, transl. P. S. Falla, Oxford, 1978.

Kutrzeba S., Polska Odrodzona 1914-1939, $5^{\text {th }}$ ed., Kraków, 1988.

Leinwand A. J., Czerwonym młotem $w$ orła białego. Propaganda sowiecka $w$ wojnie $z$ Polska 1919-1920, Warszawa, 2008.

Leinwand A. J., "Po co Polakom niepodległość? Spór w socjaldemokracji polskiej na polskiej na przełomie XIX i XX wieku," in: Imperia, narody i społeczeństwa Europy Wschodniej $i$ Środkowej na progu pierwszej wojny światowej, ed. A. Nowak, in cooperation with M. Banaszkiewicz, Warszawa, 2016.

Leinwand A. J., Sztuka w stużbie utopii. O funkcjach politycznych i propagandowych sztuk plastycznych w Rosji Radzieckiej 1917-1922, Warszawa, 1998.

Łossowski P., “Geneza niepodległości. Dyplomacja II Rzeczypospolitej,” in: Historia dyplomacji polskiej X-XX w., Warszawa, 2002.

Materski W., Na widecie. II Rzeczpospolita wobec Sowietów 1918-1943, Warszawa, 2005.

Materski W., Tarcza Europy. Stosunki polsko-sowieckie 1918-1939, Warszawa, 1994.

Nowak A., Polska i trzy Rosje. Studium polityki wschodniej Józefa Piłsudskiego (do kwietnia 1920 roku), Kraków 2001.

Pipes R., The Formation of the Soviet Union. Communism and Nationalism 1917-1923, Cambridge, Massachusetts, 1970. 
Sukiennicki W., "Przyczyny i początek wojny polsko-sowieckiej 1919-1921," part 2, Bellona 1963, fasc. 3-4.

Suleja W., Józef Piłsudski, Wrocław, 1995.

Teslar T., Propaganda bolszewicka podczas wojny polsko-rosyjskiej 1920 roku, Warszawa, 1938. Wandycz P.S., Soviet-Polish Relations, 1917-1921, Cambridge, Massachusetts, 1969.

Wereszycki H., Historia polityczna Polski 1864-1918, $2^{\text {nd }}$ ed. revised and expanded, Paryż, 1979. White S., The Bolshevik Poster, New Haven-London, 1998.

\section{Documents}

Butnik-Siversky B. S., Sovetskiy plakat epokhi grazhdanskoy voyny, Moskva, 1960.

Dokumenty i materiały do historii stosunków polsko-radzieckich, vol. 3: kwiecień 1920 - marzec 1921, Warszawa, 1964.

Dokumenty vneshnei politiki SSSR, vol. 1, Moskva, 1957.

Kumaniecki K. W., Odbudowa państwowości polskiej. Najważniejsze dokumenty. 1912 - styczeń 1924, Warszawa, Kraków, 1924.

Papers Relating to the Foreign Relations of the United States. 1917. Supplement 1. The World War, Washington, 1931.

Papers Relating to the Foreign Relations of the United States. 1918. Supplement 1. The World War, vol. 1, Washington, 1933.

Powstanie II Rzeczypospolitej. Wybór dokumentów 1866-1925, ed. H. Janowska, T. Jędruszczak, Warszawa, 1981.

Stosunki Rzeczypospolitej Polskiej z państwem radzieckim 1918-1943. Wybór dokumentów, compiled by J. Kumaniecki, Warszawa, 1991.

Aleksandra Julia Leinwand, dr. hab., professor at the Institute of History of the Polish Academy of Sciences, historian of Eastern Europe of the $20^{\text {th }}$ century, researcher of the history of propaganda and art in service of totalitarianism. Author of books such as Sztuka w stużbie utopii. O funkcjach politycznych i propagandowych sztuk plastycznych w Rosji Radzieckiej lat 1917-1922 (1998) and Czerwonym młotem w Orła Białego. Propaganda sowiecka w wojnie z Polska 19191920 (2008). (aleinwand@o2.pl)

Submitted 27.11.2018; accepted 12.03.2018 